\title{
PENGARUH CAMPURAN PELET KUDZU DENGAN KARBOHIDRAT TERHADAP PROTEIN TOTAL, UREA, GLUKOSA DAN KOLESTEROL DARAH DOMBA EKOR TIPIS
}

\section{(The Effect of Kudzu Pellet with Carbohydrates on Total Protein, Urea, Glucose and Cholesterol in plasma of Thin-Tailed Sheep)}

\author{
Muhamad Ramdhan ${ }^{1}$, Iin Susilawati ${ }^{2}$, Novi Mayasari ${ }^{2}$ \\ ${ }^{1}$ Program Studi Nutrisi Ternak, Pascasarjana Fakultas Peternakan Universitas Padjadjaran \\ ${ }^{2}$ Staf Pengajar Departemen Ilmu Nutrisi Ternak Fakultas Peternakan Universitas Padjadjaran \\ E-mail: dhan190894@gmail.com
}

Article Submitted : 15-10-2019

Article Accepted : 06-02-2020

\begin{abstract}
This research aimed to determine blood protein total, blood urea, blood glucose and blood cholseterol on thin tail rams which is administered kudzu pellet with readily available carbohydrates. Experimental method used completely randomize design. The data was analyzed through Anova and Duncan's Multiple Range Test. Twenty four local rams are divided into four dietary treatment, namely $\mathrm{RK}=50 \%$ napier grass $+50 \%$ concentrate, $\mathrm{KD}=50 \%$ napier grass + $25 \%$ kudzu pellet with rice bran $+25 \%$ concentrate, $\mathrm{KM}=50 \%$ napier grass $+25 \%$ kudzu pellet with molasses $+25 \%$ concentrate, $\mathrm{KG}=50 \%$ napier grass $+25 \%$ kudzu pellet dried cassava $+25 \%$ concentrate. Each treatment was replicated six times. Administering dried cassava $(\mathrm{KG})$ in kudzu showed significance $(\mathrm{P}<0,05)$ blood glucose in thin-tailed ram compared to control dietary (RK) and bran rice kudzu pellet (KD) based on table 2. Administering dried cassava $(\mathrm{KG})$ and molasses $(\mathrm{KM})$ in kudzu pellet provided similar response (Table 2) on blood glucose level. Blood cholesterol level decreased along with the duration of treatment (Table 2) during 60 days compared before treatment. The result showed that duration of treatment made a significant decrease $(\mathrm{P}<0,05)$ (Table 2$)$ on blood cholesterol in rams. Blood total protein declined when the treatment was administered during 60 days. The result explained that duration of treatment is significant $(\mathrm{P}<0,05)$ to decrease blood total protein level on rams (Table 2$)$. The blood urea level of this research showed that the duration of treament is significant $(\mathrm{P}<0,05)$ to increase blood urea level on thin-tailed rams (Table 2). Blood urea level on each treatment was range between $31,23 \mathrm{mg} / \mathrm{dL}-34,57 \mathrm{mg} / \mathrm{dL}$. This result explained that the increase of blood urea level showed a significant difference $(\mathrm{P}<0,05)$ when diet treatments interacted with the duration of treatment (Graph $\mathrm{C}$ ). The conclusion of this research was administering dried cassava (KG) and molasses (KM) in kudzu pellet increase blood glucose level, stabilized blood total protein, urea and cholesterol in thin-tailed rams. However, the protein balance in thin-tailed rams diet on different age should be considered in order to support the growth.
\end{abstract}

Keywords: Kudzu, Blood Urea, Blood Glucose, Blood Protein Total, Blood Cholesterol

\section{PENDAHULUAN}

Domba ekor tipis memiliki keunggulan mudah beradaptasi dengan lingkungan sehingga menjadi faktor utama pertimbangan peternak untuk membudidayakan domba ekor tipis. Pertumbuhan domba mengalami percepatan yang signifikan pada saat setelah lepas sapih (sekitar 4 bulan) sampai dengan sampai dewasa tubuh (sekitar 1 tahun) 
(Tillman et al, 1998). Laju pertumbuhan domba setelah disapih ditentukan oleh beberapa faktor, antara lain potensi pertumbuhan dari masing-masing individu ternak dan pakan yang tersedia (Colomerrocker $d k k$, 1992). Pertumbuhan domba yang baik harus ditunjang oleh ketersediaan sumber hijauan dan konsentrat yang berkualitas dan tersedia sepanjang waktu.

Kudzu merupakan salah satu hijauan leguminosa yang memiliki protein kasar cukup tinggi sebesar 17,4 - 19,3 \% (Hartadi et al, 1997). Tanaman kudzu memiliki serat kasar yang cukup tinggi dengan kandungan energi yang rendah. Upaya untuk menanggulangi defisiensi energi dari tanaman kudzu sebagai konsentrat perlu ditambahkan karbohidrat siap pakai. Beberapa karbohidrat siap pakai yang digunakan yaitu gaplek, molases dan dedak padi. Gaplek merupakan produk olahan yang terbuat dari singkong yang telah dikeringkan. Gaplek adalah salah satu bahan pakan sumber energi. Kandungan nutrisi gaplek yaitu bahan kering $85,2 \%$, protein kasar $1,8 \%$, serat kasar $2,8 \%$, lemak kasar $0,2 \%$ dan TDN sebesar $84 \%$ (Hartadi dkk, 1993) Gaplek baik digunakan sebagai bahan konsentrat untuk ruminansia (Antari dkk, 2009).. Pati yang terkandung dalam gaplek yaitu $81,6 \%$ yang terdiri dari dua komponen yang dapat dipisahkan yaitu amilosa dan amilopektin. Kadar amilosa dan amilopektin pada gaplek yaitu masing-masing $17 \%$ dan $83 \%$ (Herlina dan Noerdin 2008). Karbohidrat siap pakai yang sering digunakan peternak lainnya adalah molasses. Molases merupakan hasil pengolahan gula tebu ataudikenal dengan nama tetes tebu. Molases mengandung sukrosa, glukosa, fruktosa dan rafinosa dalam jumlah yang besar serta sejumlah bahan organik non gula (Valli et al., 2012). Molases sering ditambahkan ke dalam ransum untuk meningkatkan palatabilitas, aktivitas mikroba rumen, sintesis protein mikroba dan menurunkan jumlah unsur debu dalam pakan kering (da Costa et al., 2015). Dedak merupakan karbohidrat siap pakai yang kaya akan sumber vitamin B dan disukai ternak.
Dedak padi mengandung protein kasar 11,9$13,4 \%$, serat kasar $10-16 \%$, total digestible nutrirnt (TDN) 70,5-81,5\%, energi metabolisme $2730 \mathrm{kkal} / \mathrm{kg}$, dan mineral $\mathrm{Ca}$ $0,1 \%$ dan $\mathrm{P} 1,51 \%$. Penggunaan dedak padi dalam ransum ruminansia maksimum $40 \%$ total ransum (Ako, 2013).

Hingga saat ini pemberian kombinasi berbagai karbohidrat siap pakai pada pembuatan pelet berbasis kudzu pada domba belum banyak dilakukan. Tersedianya karbohidrat siap pakai dalam kadar tertentu diharapkan mampu memenuhi kebutuhan glukosa di dalam darah domba serta menjaga kestabilan kandungan kolesterol dalam darah domba namun kandungannya rendah pada daging sehingga aman dikonsumsi. Selain itu diharapkan terjadi peningkatan kecernaan protein yang tergambar dari protein total dan urea darah. Berdasarkan studi literature, kajian mengenai pemberian karbohidrat siap pakai pada pellet kudzu yang terhadapstatus metabolit belum banyak dilakukan.

Berdasarkan uraian diatas dapat ditarik hipotesis bahwa pemberian molasses pada pellet kudzu dapat meningkatkan protein total, urea dan glukosa darah serta dapat menstabilkan (kadar normal) kolesterol darah domba ekor tipis.

\section{METODE PENELITIAN}

Ternak yang digunakan dalam penelitian ini berjumlah dua puluh empat ekor domba jantan ekor tipis, berumur 5-6 bulan dengan rata-rata bobot badan awal $13,16 \mathrm{~kg}$, dengan koefisien variasi sebesar 13,79 \%. Pemindahan domba dari kandang koloni ke kandang individu dengan lama adaptasi yaitu 2 minggu. Tujuan adaptasi ternak adalah untuk menghindari stres pada domba yang ditimbulkan karena kondisi kandang yang berbeda.

Bahan pakan penyusun ransum penelitian terdiri atas kudzu dalam bentuk tepung yang dipeletkan, rumput gajah, konsentrat dan karbohidrat siap pakai seperti gaplek, dedak dan molases. Pembuatan pelet kudzu dilakukan dengan cara kudzu dikeringkan 
terlebih dahulu kemudian digiling, dan dicampur dengan bahan pakan lain kemudian dibuat kedalam bentuk pelet melalui mesin pelet. Ketiga karbohidrat siap pakai tersebut masing-masing ditambahkan kedalam pelet kudzu dan diberikan ke domba penelitian dengan persentase yang sama. Pembuatan pelet kudzu dilakukan dengan cara pengeringan, digiling lalu dicampurkan dengan konsentrat kemudian diubah oleh mesin pelet serta terakhir dikeringkan.

Pemeliharaan terdiri dari pemberian pakan, pengecekan kesehatan, penimbangan bobot badan. Lama pemeliharaan dilakukan selama 2 bulan setelah fase adaptasi kandang dan pakan. Pemberian pakan diberikan tiga kali sehari. Sisa pakan ditimbang dan dicatat sebelum pemberian pakan baru saat pagi hari. Domba ditimbang setiap satu bulan sekali.

Sampel darah diambil dengan cara mengambil darah domba sebelum diberikan perlakuan (0 hari), pertengahan perlakuan (30 hari) dan akhir perlakuan (60 hari). Masingmasing domba diambil darahnya sebanyak 5 $\mathrm{ml}$ melalui vena jugularis dengan menggunakan spuit miring $10 \mathrm{ml}$. Darah kemudian dimasukkan ke dalam tabung EDTA. Sampel darah dibawa ke laboratorium untuk dilakukan sentrifuse dengan kecepatan 3000 rpm selama 10 menit untuk mendapatkan sampel plasma. Sampel plasma dimasukkan ke dalam tabung PCR (eppendorf $\AA$, Hamburg, Jerman) kemudian disimpan dalam suhu - 20 ${ }^{\circ} \mathrm{C}$ sebelum dilanjutkan dengan analisis darah.

Parameter yang diuji adalah kadar protein total, urea, kolesterol dan glukosa darah. Penelitian ini dilakukan dengan metode eksperimental menggunakan Rancangan Acak Lengkap (RAL) yang terdiri dari 4 perlakuan dan 6 pengulangan pada setiap perlakuan. Perlakuan yang diberikan adalah sebagai berikut $\mathrm{P}_{0}=50 \%$ Rumput Gajah $+50 \%$ Konsentrat, $\mathrm{P}_{1}=50 \%$ Rumput Gajah $+25 \%$ Pelet Kudzu Gaplek $+25 \%$ Konsentrat, $\mathrm{P}_{2}=$ $50 \%$ Rumput Gajah $+25 \%$ Pelet Kudzu Molases $+25 \%$ Konsentrat dan $\mathrm{P}_{3}=50 \%$ Rumput Gajah $+25 \%$ Pelet Kudzu Dedak + $25 \%$ Konsentrat.

Analisis sidik ragam digunakan pada penelitian guna mengetahui pengaruh perlakuan terhadap peubah, sedangkan untuk mengetahui perbedaan antar perlakuan $(\mathrm{P}<0,05)$ dilakukan Uji Jarak Berganda Duncan dengan menggunakan software SPSS versi 24.

Tabel 1. Kandungan Nutrien Ransum Penelitian

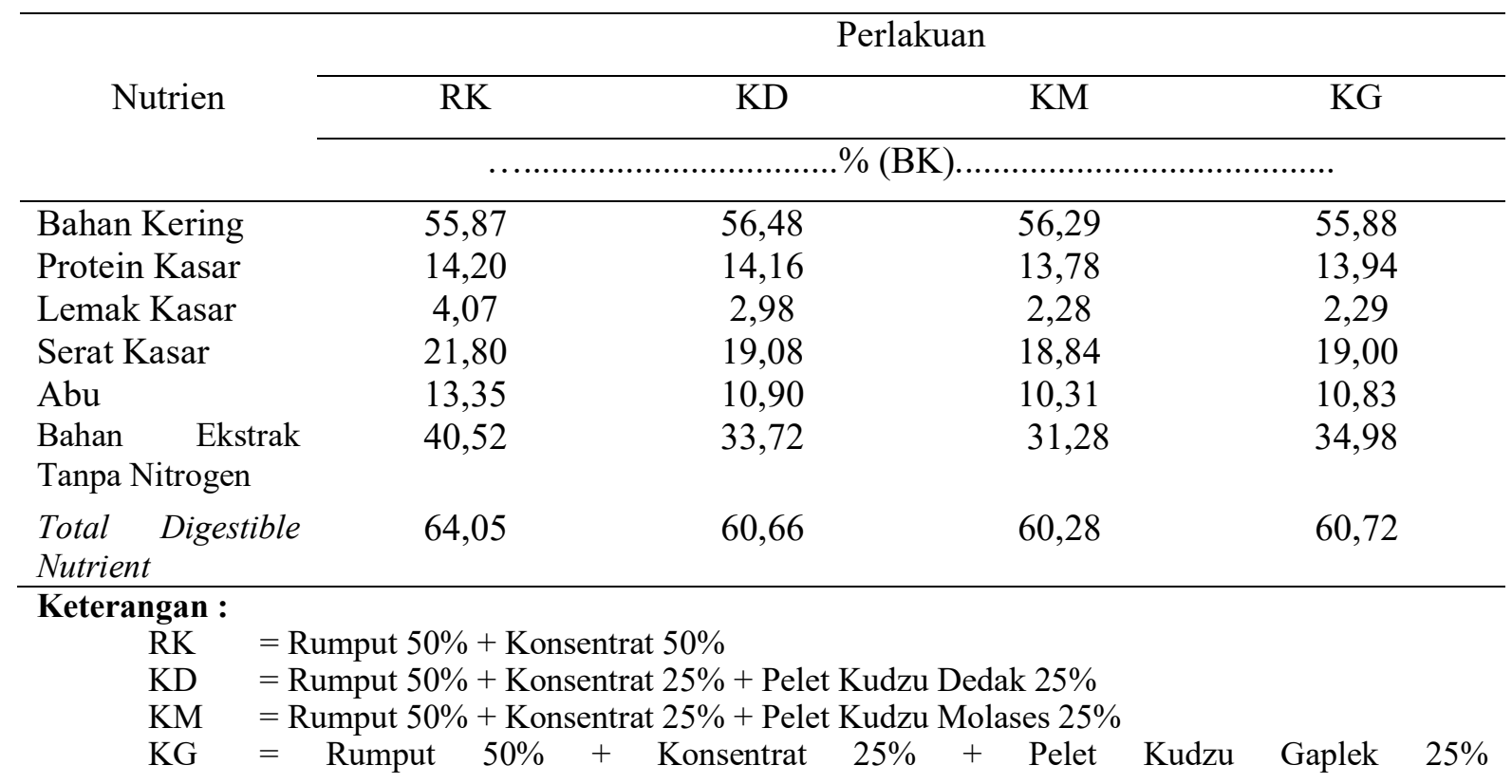




\section{HASIL DAN PEMBAHASAN}

Pemberian gaplek (KG) pada pelet kudzu berpengaruh nyata $(\mathrm{P}<0,05)$ berdasarkan tabel 2. terhadap peningkatan kadar glukosa darah domba ekor tipis dibandingkan dengan pemberian ransum kontrol (RK) dan pelet kudzu dedak (KD). Pemberian gaplek (KG) dan molases (KM) pada pelet kudzu memberikan respons yang sama (Grafik A) terhadap kadar glukosa. Rataan nilai glukosa darah dalam penelitian ini adalah sebesar $80,01 \mathrm{mg} / \mathrm{dL}$. Menurut Chyntia (2005) nilai normal glukosa darah domba adalah $44-81$ $\mathrm{mg} / \mathrm{dL}$. Kadar glukosa darah dalam penelitian ini masih dalam kadar normal. Pada penelitian ini nilai glukosa darah cukup tinggi dibandingkan dengan nilai rata-rata glukosa darah domba ekor tipis pada umumunya . Hal tersebut merupakan suatu indikator yang baik mengingat domba muda memerlukan banyak cadangan energi guna menunjanng pertumbuhannya. Selain itu hal tersebut dapat terjadi dikarenakan pati yang terkandung dalam gaplek yaitu $81,6 \%$ yang terdiri dari dua komponen yang dapat dipisahkan yaitu amilosa dan amilopektin. Kadar amilosa dan amilopektin pada gaplek yaitu masing-masing $17 \%$ dan $83 \%$. Penyusun senyawa amilosa dan amilopektin adalah glukosa sehingga dapat meningkatkan aktivitas mikroba rumen untuk menghasilkan produk VFA (Volatile fatty acid) (Herlina dan Noerdin, 2008). Sedangkan pada KM, nilai glukosa darah lebih rendah jika dibandingkan dengan KG (Tabel 2.). Hal tersbut dapat terjadi karena kandungan karbohidrat pada molases yang lebih sederhana dibandingkan dengan gaplek sehingga proses degradasi didalam rumen menjadi cepat (fast release).

Kadar kolesterol darah menurun seiring dengan penambahan lama waktu perlakuan (tabel 2.) selama 60 hari dibandingkan dengan sebelum diberikan perlakuan. Sebelum perlakuan, rataan nilai kolesterol berada pada kisaran 100,6 mg/dL (Tabel 2.) dan menurun sebanyak 47,87 persen (Grafik B) setelah diberi perlakuan selama 60 hari. Hasil menunjukkan bahwa lama waktu perlakuan dapat berpengaruh nyata $(\mathrm{P}<0,05)$ (Tabel 2.) terhadap penurunan kadar kolesterol darah domba. Kadar kolesterol darah pada tiap perlakuan berada dalam kisaran normal yaitu $69,97 \mathrm{mg} / \mathrm{dL} \mathrm{mg} / \mathrm{dL}$. Smith dan Mangkoewidjojo (1998) menyatakan bahwa kondisi normal kolesterol darah pada domba adalah 50-140 mg/dL. Sehingga dalam perlakuan ini nilai kolesterol darah masih berada dalam kisaran normal. Penyebab berkurangnya nilai kolesterol darah dalam penelitian dapat terjadi karena kolesterol merupakan senyawa yang berperan dalam perkembangan organ reproduksi domba jantan untuk mencapai dewasa tubuh dan kelamin (Nalbandov, 1990). Menurut Tranggono (2001) kolesterol adalah bahan dasar pembentukan hormon steroid yang mencakup testosteron dan estrogen. Namun hal yang perlu dicermati adalah penurunan kolesterol darah dibawah rentang normal menjadi sesuatu yang berdampak buruk bagi domba jantan yang akan menjadi replacement stock sebab domba jantan yang digunakan dalam penelitian ini merupakan domba muda yang berumur 5-7 bulan sehingga memerlukan kolesterol guna membangun jaringan reproduksi domba tersebut.

Kadar protein darah menurun dalam waktu perlakuan selama 60 hari (Grafik D). Sebelum perlakuan rataan nilai protein total berada pada kisaran $6,21 \mathrm{~g} / \mathrm{dL}$ dan menurun sebanyak 7,72 persen (Tabel 2.) setelah diberi perlakuan selama 60 hari. Hasil penelitian menunjukan bahwa lama waktu perlakuan memberikan hasil yang signifikan (Tabel 2.) terhadap penurunan nilai protein total darah pada domba $(\mathrm{P}<0,05)$. Rataan kadar protein total pada penelitian adalah sebesar 5,64 $\mathrm{mg} / \mathrm{dL}-6,05 \mathrm{mg} / \mathrm{dL}$. Selanjutnya, berbanding terbalik dengan pengaruh waktu perlakuan terhadap kadar protein. Kadar urea darah hasil penelitian ini menunjukan bahwa waktu perlakuan memberikan pengaruh yang nyata $(\mathrm{P}<0,05)$ terhadap peningkatan kadar urea darah (Tabel 2.) domba ekor tipis. Kadar urea darah pada tiap perlakuan adalah sebesar 31,23 $\mathrm{mg} / \mathrm{dL}-34,57 \mathrm{mg} / \mathrm{dL}$. 
Tabel 2. Pengaruh Perlakuan Terhadap Protein Total, Urea, Kolesterol dan Glukosa Darah

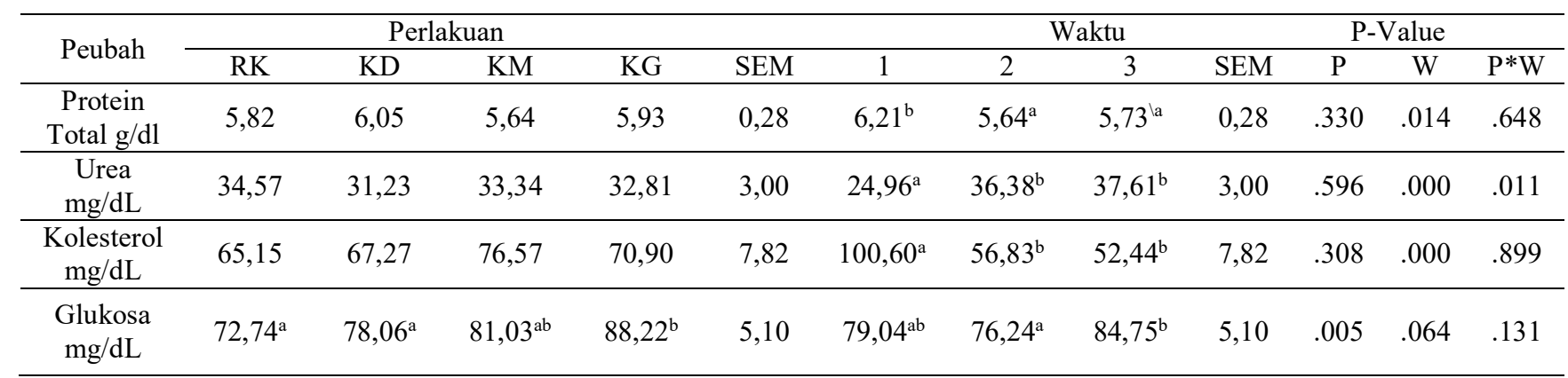

Rata-rata yang diikuti dengan superscript pada baris yang sama menunjukkan tidak berpengaruh nyata $(p>0,05)$

\section{Keterangan :}

RK = Rumput $50 \%+$ Konsentrat $50 \%$

$\mathrm{KD}=$ Rumput $50 \%+$ Konsentrat $25 \%+$ Pelet Kudzu Dedak $25 \%$

$\mathrm{KM}=$ Rumput 50\% + Konsentrat 25\% + Pelet Kudzu Molases 25\%

$\mathrm{KG}=$ Rumput 50\% + Konsentrat 25\% + Pelet Kudzu Gaplek 25\%

$\mathrm{SEM}=$ Standar eror means

$\mathrm{P} \quad=$ Perlakuan

$\mathrm{W} \quad=$ Waktu

Hasil penelitian membuktikan bahwa peningkatan nilai urea darah menunjukan adanya perbedaan yang nyata $(\mathrm{P}<0,05)$ ketika perlakuan pakan berinteraksi dengan waktu perlakuan (Grafik C). Hal utama yang dapat terjadi adalah imbangan protein dalam pakan menjadi tidak seimbang ketika umur domba terus bertambah dikarenakan terjadinya penurunan terus meneruss terhadap nilai protein total darah pada domba. Hal lain yang dapat terjadi karena domba ekor tipis yang digunakan dalam penelitian ini berumur muda yaitu 5-7 bulan. Sehingga penggunaan protein di dalam tubuh digunakan untuk pembentukan jaringan tubuh, pembentukan daging dan sebagai penyusun hormon serta enzim yang berguna untuk pertumbuhan domba muda tersebut. Hal tersebut sesuai dengan yang dikatakan oleh Tillman et al (1998) bahwa puncak pertumbuhan pada masa-masa lepas sapih (sekitar umur 4 bulan) sampai dewasa tubuh (sekitar 1 tahun). Sesuai yang dikatakan Tillman et al (1998) bahwa puncak pertumbuhan terjadi hingga dewasa tubuh. Sehingga sisa metabolisme protein berupa urea meningkat dengan signifikan di dalam tubuh. Maka dapat dijelaskan bahwa kebutuhan domba akan protein untuk menunjang pertumbuhan meningkat seiring umur domba bertambah sebelum mencapai dewasa tubuh sehingga imbangan protein pada setiap fase umur menjadi hal krusial. Maka imbangan protein dalam pakan perlu dihitung kebutuhunnya pada setiap fase guna menunjang kebutuhan protein untuk pertumbuhan domba jantan ekor tipis tersebut. 


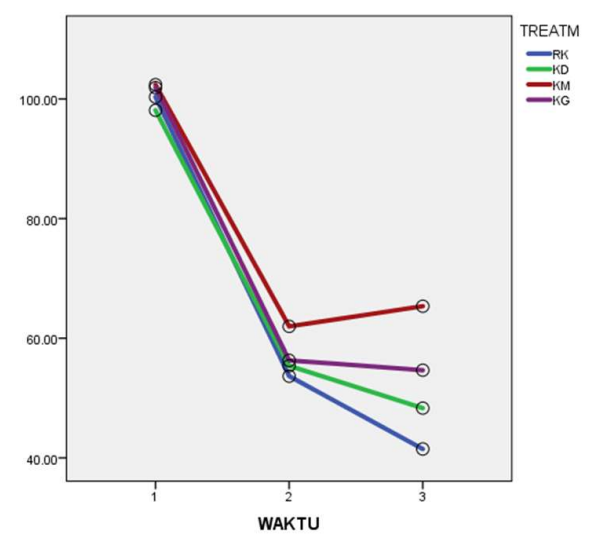

a.

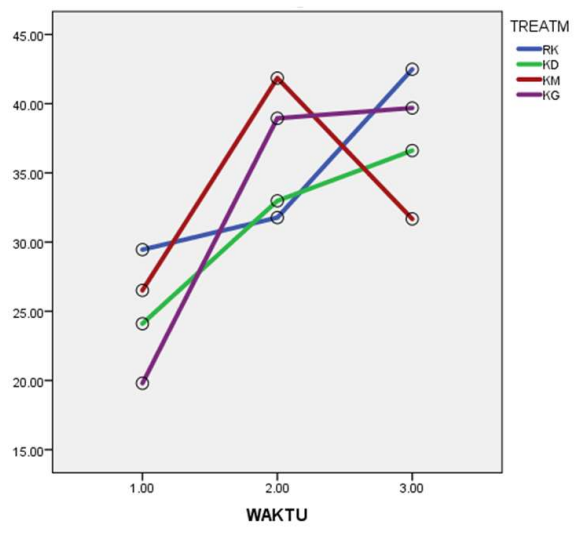

c.

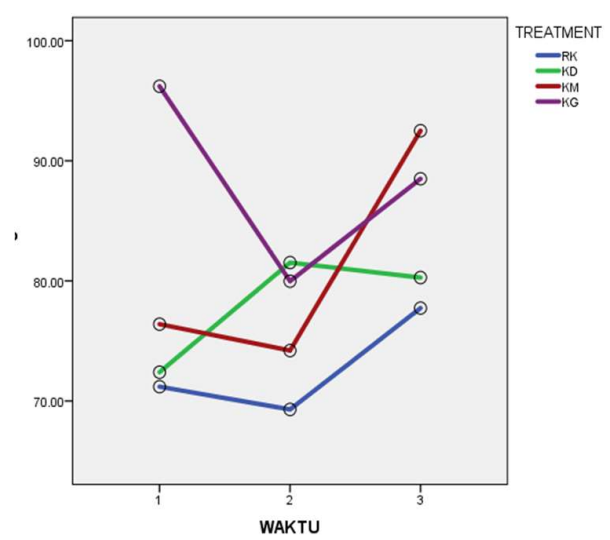

b.

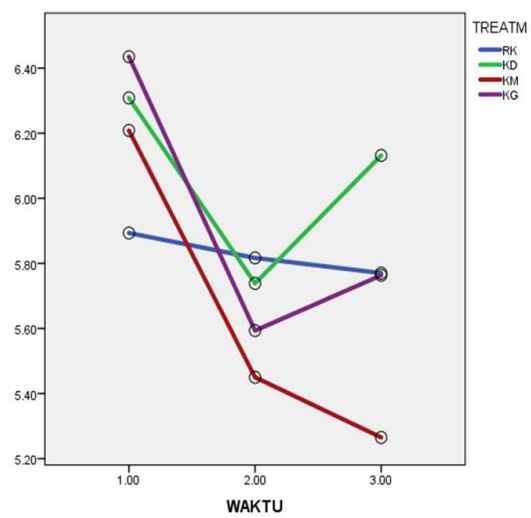

d.

Grafik a. Pengaruh Perlakuan terhadap kadar glukosa darah pada berbagai waktu. Grafik b. Pengaruh Perlakuan terhadap kadar kolesterol darah pada berbagai waktu Grafik c. Pengaruh Perlakuan Terhadap Kadar Urea Darah pada Berbagai Waktu. Grafik d. Pengaruh Perlakuan Terhadap Protein Total Darah pada Berbagai Waktu

\section{KESIMPULAN}

Kesimpulan dari penelitian ini adalah pemberian gaplek dan molases pada pelet kudzu dapat meningkatkan glukosa darah, menstabilkan protein total, urea dan kolesterol darah domba jantan ekor tipis. Namun perlu dicermati kebutuhan imbangan protein pakan untuk domba jantan ekor tipis pada umur yang berbeda untuk menunjang pertumbuhan domba.

\section{DAFTAR PUSTAKA}

Ako, A. 2013. Ilmu Ternak Perah Daerah Tropis. Penerbit IPB Press. Bogor

Astuti, D., Suprayogi, A., Marwah, D.R. dan Suryani. 2006. Status Nutrien dan Gambaran Darah Domba Lokal yang Dipelihara di Hutan Pendidikan Gunung Walat Sukabumi. Seminar Nasional Teknologi Peternakan dan Veteriner. Fakultas Peternakan. Institut Pertanian Bogor. 
Cheng ZJ. dan Hardy, R.W . 2004. Protein and lipid sources affect cholesterol concentrations of juvenile Pacific white shrimp, Litopenaeus vannamei (Boone). Journal of Animal Science 82(4):1136-1145.

ColomerRocker, F., Kirton, A.H., Mercer, G.J., Kand Duganzich, D.M. 1992. Carcass composition of New Zealand Saanen goats slaughtered at different weights. Small Ruminant Resume. 7: $161-173$.

Cynthia M. K. dan Scott L. (Ed). 2005. The Merck Veterinary Manual. $9^{\text {th }}$ ed. New Jersey (US): Kahn CM Merck \& Co Inc.

Desmiaty, Y., Ratih, H., Dewi, MA., Agustin, R. 2008. Penentuan jumlah tanin total pada daun jati belanda (Guazuma ulmifolia Lamk) dan daun sambang darah (Excoecaria bicolor Hassk.) secara kolorimetri dengan pereaksi biru prusia. Ortocarpus. 8: 106-109.

Hartadi, H., Reksohadiprodjo, S., Tillman, A.D. 1997. Komposisi Bahan Pakan Untuk Indonesia. Gadja Mada University Press, Yogyakarta.
McDonald dan Morgan, C.A. 2002. Animal Nutrition. $\quad 5^{\text {th }}$ Edition. Longman Scientific and Technical, Inc. New York

Riis, P. M. 1983. Dynamic Biochemistry of Animal Production. Elsevier. New York.

Smith, B. J. B dan Mangkoewidjojo, S. 1998. Pemeliharaan Pembiakan dan Penggunaan Hewan Percobaan di Daerah Tropis. Universitas Indonesia. Jakarta.

Tillman, A. D., Hartadi, H., Reksohadiprojo, S., Prawirokusumo, S. dan Lebdosoekojo, S. 1998. Ilmu Makanan Ternak Dasar. Edisi ke-5. Gadjah Mada University Press, Yogyakarta

Valli, V., Gomez-Caravaca,'A.M., Di Nunzio, M., Danesi, F., Caboni, M. F., dan Bordoni, A. 2012. Sugar Cane and Sugar Beet Molasses, Antioxidant-rich Alternatives to Refined Sugar. J. Agric. Food Chem. 60: 12508-12515. dx.doi.org/10.1021/jf304416d 